\title{
THE MOAKLEY-DeCONCINI BILL
}

The situation facing refugees in flight from civil strife in El Salvador has changed little since 1983 when legislation was first introduced that would provide Salvadorans limited protection in the U.S. The legal context, however, of conditions facing the undocumented refugee community has changed significantly. Within the past year, the U.S. has experienced dramatic changes in immigration/political asylum law and practice. Recent legislation and litigation have produced new policy responses to a number of relevant issues involving reception of the undocumented asylum seeker in the U.S. Landmark changes in immigration policy include: passage of the Immigration Control and reform Act (IRCA); the decision by the U.S Supreme Court (in Cardoza-Fonseca) to affirm the more objective "well-founded fear of persecution" asylum standard; the well publicized announcement by Attorney General Meese regarding preferential treatment and protection of Nicaraguans here by granting them rights already due Nicaraguans and others presently in the U.S.; prosecution and conviction of sanctuary workers providing refuge to refugees from El Salvador and Guatemala; expansion of immigration detention sites throughout the U.S. for incarceration of asylum seekers; and completion of two relevant General Accounting Office (GAO) studies regarding a) discrimination against Salvadorans in political asylum adjudication practice, and $b$ ) inconclusive analysis of evidence claiming safe return for repatriated Salvadorans. These significant events are exacerbated by proposed changes in Canadian immigration policy

Cont'd on page 5

\section{Cont'd from page 3}

work authorization by the I.N.S. even though the I.N.S. regulations explicitly state that refugees who present "nonfrivolous" applications for political asylum should be granted permission to work.

For the second point, those Central Americans who do not qualify for legalization under the Amnesty Law, will be deeply affected by the employer sanctions, by which employers of "illegal immigrants" and others without work authorization are subjected to fines and penalties. These sanctions will only serve to marginalize many sectors of the Central American immigrant community, lowering their already poor standard of living and increasing employer exploitation. Fear of detection and subsequent deportation will force many refugees to tolerate victimization, exploitation and racism by employers. Refugee organizations are already reporting massive layoffs of workers who are unable to prove that they were authorized to work in the United States even before the imposition of employer sanctions. Many refugees have reported that their wages have already been lowered by employers who are taking advantage of the vulnerability of the workers who do not have work authorization.

The I.N.S. has stated that the "alternative" to legalization for the hundreds of thousands of Central American refugees who do not qualify for legalization continues to be application for political asylum. However, applying for political asylum has not proven to be a viable option for these refugees due to the disproportionate denial rate. Statistics show that from the period 1981 through 1984, more than 32,241 Salvadoran refugees applied for political asylum in the United States. Five hundred and sixty two of those applications were approved, while another 20,833 applicants were denied, an approval rate of less than 3 per cent. The approval rate is even lower for Guatemalan refugees.

In response to the growing concern over the future impact of the new Immigration and Reform Control Act on their lives, many Central American refugees began to flee to Canada in late 1986, presenting themselves at the border where they requested political asylum. Canada, under its Ministerial Permit program in existence at that time, was not deporting Central American refugees and routinely issued ministerial permits to refuge-seekers originating from a list of 18 countries which included El Salvador and Guatemala. Refugees from these countries were allowed to stay in Canada and given work permits while awaiting a determination of their cases. This special program was abruptly ended by the Canadian government on February 20,1987, in light of the flow of refugees requesting political asylum at Canadian borders at the rate of 1,000 to 1,200 arrivals per week

The Canadian government has subsequently reiterated its commitment to lend its hand in alleviating the Central American refugee problem by encouraging Central Americans to apply for political asylum outside Canada at the nearest Canadian Consulate. However, Canada has put restrictions on the number of refugees it will sponsor a year. In 1986, the Canadian government only sponsored approximately 3,300 Central American refugees, a very small number considering that since the civil war in $\mathrm{El}$ Salvador approximately one fifth of the population was forced to flee the country.

The Canadian government's recent increase of restrictions on access of Central American refugees to Canada, and the U.S.government's attempt to stem the flow of illegal immigration by passing employer sanctions, only shows that these governments are refusing to deal with the root causes of the refugee problems: these are the civil conflict and persecution existing in their Central American countries of origin which cause them to flee.

It is clear that what is needed is a regional response to the growing number of Central Americans who are fleeing their homelands. The United States, along with Mexico, Canada and other countries in the region should commit themselves to the international principle of non-refoulement (no forced) return for Central American refugees. A temporary haven should be granted to these refugees who because of the violence and civil unrest in their homelands cannot safely return. Passage of such proposed legislation as the (U.S.) Moakley-Deconcini refugee protection bill which would grant a temporary suspension to the detention and deportation of Salvadoran refugees in the U.S. would be a step in the right direction toward alleviating the plight of the Central American refugees.

Kathy Alfred has been a Staff Officer at the Los Angeles Center for Law and Justice since 1984. 


\section{Cont'd from page 4}

that would restrict reception of Salvadoran refugees coming directly from the United States (in particular, new legislation bills C-84 and C-55).

As such policies were lobbied for, voted upon and implemented in Washington, D.C., the United States was experiencing a heavy refugee influx from El Salvador. Mass migration from the region, caused by El Salvador's civil war, has brought hundreds of thousands of undocumented refugees to the U.S.. By 1987, more than $20 \%$ of El Salvador's population had become refugees or displaced persons within the country. In addition to United Nations, church, and government refugee camps established in Mexico, Honduras and other Central American countries, great numbers of refugees sought first asylum in the U.S., in Los Angeles, San Francisco, Chicago, New York, Miami, Boston and, perhaps, ironically, in Washington, D.C. where policies restricting refugee protection are formulated

The above provides a backdrop in discussion of the labored Salvadoran safe haven bill sponsored by Rep. Moakley (D-MA) of the House of Representatives and Senator DeConcini (D-AZ) on the Senate side. In its four year legislative history, the Moakley-DeConcini bill has made limited headway amid a dramatically changing landscape of immigration law. Despite its legacy of testimony covering issues on the root causes of civil strife in Central America and U.S. practice in the region, the Moakley-DeConcini bill has moved slowly in comparison to other initiatives. Progress, however, is on the horizon. On July 28, 1987, the U.S. House of Representatives unanimously passed the Moakley bill (renamed the Central American Studies and Temporary Relief Act of 1987). Later this Fall, the DeConcini bill is expected to reach the Senate floor for a final vote. With significant amendments attached to the bills, the conference committee selected to reconcile the differences between the House and Senate version will play a significant role.

\section{Legislative History}

Generated in response to conditions of warfare, human rights abuses and violence in El Salvador, the Moakley-DeConcini (herein referred to as Moakley) bill was initially drafted in support of providing temporary safety for an estimated quarter mil- lion refugees in the U.S. Now, four years later, after nearly 70,000 civilians have lost their lives to war in El Salvador, and as hundreds of thousands have become displaced within the region of Honduras, Guatemala, Mexico, Belize, Nicaragua and Costa Rica, more than 500,000 Salvadorans seek safe haven in the U.S. With worsening political and economic conditions and increased destruction of life and property, El Salvador continues to be a country ravaged by a nine year civil war. As other forms of protection are offered to nationalities from countries in similar circumstances, such as Poles, Afghanis, and Ethiopians, Salvadorans still do not receive blanket protection. Political asylum approval rates for Salvadorans are abysmally low. As the subject of a recent GAO study investigating apparent discrimination in adjudication of asylum claims, Salvadoran asylum applicants currently average a less than $3 \%$ approval rate, as compared, for example, to an $85 \%$ approval rate to date for Nicaraguans. ${ }^{1}$ Further, Salvadorans have become the typical detainee in any one of the Immigration Service's many immigration detention centers. These centers, or immigration prisons, incarcerate undocumented persons for lengthy periods for having violated the crime of illegal entry. Salvadorans are routinely detained and deported without benefit of counsel.

In response, after years of denied requests to the U.S. Government to grant Extended Voluntary Departure (E.V.D.) to Salvadorans, refugee advocates turned to sympathetic Congressional members for support. Out of this effort, Representative J.Moakley offered his first House resolution favoring suspension of detention and deportation for Salvadorans in the U.S.

Initially begun as a Sense of Congress Resolution, the Moakley bill was first drafted and passed in 1983 as a non-binding gesture in support of providing temporary safe haven for Salvadoran refugees. Now before the 100th Congress, four years later, the Moakley bill has inched its way closer to final passage.

In brief, the Moakley bill provides for an in-depth GAO study that will investigate and report to Congress on conditions for the displaced within El Salvador and throughout the region. The study will also include an examination and analysis of conditions facing those deported from the U.S. back to El Salvador and Nicaragua. An especially interesting addition to the bill includes a comparative analysis of the treatment and reception of Salvadorans and Nicaraguans in the U.S. vis-a-vis the situation of other nationals in the U.S. who have been granted Extended Voluntary Departure. ${ }^{2}$ Special attention will also be paid to the situation of undocumented Salvadorans in the U.S. A suspension of detention and deportation will be granted to Salvadorans lending completion and review of the study. This GAO study will conclude with a Congressional review of the report's findings. Upon review, Congress will implement appropriate steps in accordance with the report's conclusions.

Relatively limited in language the bill has raised relevant issues far and above the few remedies it seeks. With issues pertinent to refugee protection, domestic and foreign policy, discrimination and human rights, the Moakley bill has represented hope and haven to an estimated half million Salvadoran refugees seeking first asylum in the U.S. The language of the bill has changed much over time in incremental concessions to Congressional members seeking to dilute the political issues inherent in the bill. Rarely acknowledged officially, the unspoken subtext of the bill related immigration policy to foreign policy objectives. In essence, recognition of Salvadorans as refugees in the U.S. would directly contradict administration claims that conditions in El Salvador are improving and that President Duarte is in control of the military and paramilitary death squads.

Like most legislation, components of the bill have been criticized by those on both sides of the issues involved. Staunch advocates favoring refugee rights have recently withdrawn support of the bill in rejection of the many concessions added over time; others dub the bill an open door to "economic migrants" and allege that refugees will falsely claim fear of persecution in Central America in order to gain entry to the U.S. Long considered a liberal gesture supported almost exclusively by Democrats, the bill has been transformed year after year in an attempt to capture bipartisan support, A number of incremental changes have fundamentally altered the bill. A major change involves inclusion of Nicaraguans, added to broaden Congressional support. Other changes included restrictive language to limit those who might qualify.

\section{Cont'd on page 6}

